\title{
Failure of Media Self-Regulation? Documenting Stakeholders' Attitude to the Botswana Media Complaints/Appeals Committees
}

\author{
Eno Akpabio*, Seamogano Mosanako \\ Department of Media Studies, University of Botswana, Gaborone, Botswana \\ Email:*enoakpabio@gmail.com
}

How to cite this paper: Akpabio, E. and Mosanako, S. (2018) Failure of Media Self-Regulation? Documenting Stakeholders' Attitude to the Botswana Media Complaints/Appeals Committees. Open Journal of Social Sciences, 6, 144-157. https://doi.org/10.4236/jss.2018.62013

Received: December 28, 2017

Accepted: February 24, 2018

Published: February 27, 2018

Copyright ( 92018 by authors and Scientific Research Publishing Inc. This work is licensed under the Creative Commons Attribution International License (CC BY 4.0).

http://creativecommons.org/licenses/by/4.0/

\begin{abstract}
In Botswana, efforts at self-regulation resulted in the setting up of the Media Complaints and Appeals Committees in 2005 under the aegis of the Botswana Press Council. This study sought to find out the attitude of stakeholders to the committees by conducting intensive interviews with complainants, editors as well as members of the complaints and appeals committees. There were variances in our findings with complainants largely dissatisfied with the committees' work while the committees felt they had done a good job by providing fair rulings. And media editors said that they complied with rulings of the complaints and appeals committees but complainants took the opposite view. While two press councils are in existence at the moment, the object lesson from the Botswana scenario is that if the media are effective in their self-regulation initiatives, this will likely keep government-initiated statutory press councils at bay. The study concludes that perhaps, citizen involvement would serve to break the present impasse and ensure a media that truly serves the public interest.
\end{abstract}

\section{Keywords}

Press Council, Ethics, Compliance, Botswana, Complaints Committee, Self-Regulation

\section{Introduction}

All over the African continent, it seems political office holders are itching to regulate or control the media. This comes in various guises: subtle forms include taking on the responsibility for the sanitization of the industry in order to make for more professionalism, taking the intimidation route by raiding media hous- 
es, seizing copies of publications to imprisonment or disappearance of media professionals [1] [2] [3].

Whether this intolerance towards dissent and criticism is rooted in African culture and way of life need not detain us here. The fact remains that this ambivalent posture has made the need for self-regulation an urgent undertaking. Moreover, it is best to self-regulate before governments "help" to set up press councils for this purpose. The South African media, for instance, is reported to be replacing its Founding Bodies' Committee with a council to be governed by the Ombudsman [4]. Thankfully, there is an independent co-regulation mechanism in place consisting of the press council, press ombudsman and the appeals committee [5].

Concerns have been expressed about government involvement in the regulation of the media in Africa [6]. While many may agree that the press has excesses, even within the media establishment, the thought of government coming into the picture is not an appealing one at all. Lord Wakeman, former Chair of the British Press Council, expressed this sentiment aptly when he remarked that the long tradition of freedom of expression and British democracy would face grave dangers if government decided that self-regulation by the media had failed and then proceeded to legislate to control the media [7].

The Botswana Press Council set up the media complaints and appeals committees precisely to check such excesses. What is unclear is how these committees have performed and how those at the receiving end of unfair press as well as other stakeholders including committee members rate this self-regulatory mechanism. The present study set out to address this gap by documenting the views of journalists, complainants as well as members of the complaint and appeals committees.

\section{Botswana Press Council and the Media Complaints and Appeals Committees}

In Botswana, efforts to self-regulate predates the Mass Media Communication Bill 2001 proposed by government which met stiff resistance from MISA (Media Institute of Southern Africa) Botswana [8] as well as the International Federation of Journalists [9]. But this apparently set media professionals thinking along the lines of self-regulation. In 2002, a meeting of the Media Self-Regulation Task Force was convened by the Botswana chapter of the Media Institute of Southern Africa (MISA) and the Botswana Media Consultative Council (BMCC). The meeting authorized Joao Carlos Salbany to register the Notarial Deed of Trust of the Press Council of Botswana [10].

The Press Council of Botswana has as one of its organs the Media Complaints and Appeal Committees which are intended to ensure compliance with the Media Code of Ethics and thus maintain the atmosphere of self-regulation. Guidelines for lodging complaints as outlined by the committee are as follows: Persons aggrieved by media content or who perceive some ethical violations are allowed 
to lodge complaint(s) and the complaint committee would evaluate the merit of the complaint after obtaining the response of the affected media house. Before lodging a complaint, aggrieved persons are required to contact the media organization directly and it is only if the latter is recalcitrant that they should approach the committee.

The committee does not handle matters that have been referred to the courts and complainants waive their rights to seek legal redress by bringing their cases before the committee. The powers and authority of the Complaints' Committee are as follows:

1) To investigate an alleged infringement of the code of conduct by a member of the Press Council or print, broadcast or electronic media

2) To consider and adjudicate matters of complaints subject to its jurisdiction and thereafter dismiss, record, criticize, reprimand and make directions as to publication

3) To develop rules of procedure of [lodging] complaints by the public and elaborate [on the] codes of practice as may be appropriate

4) To promote the highest proof (sic) [professional] and ethical standard by ensuring dissemination of accurate and balanced information

5) To implement and enforce the Botswana Media Code of Ethics

6) To draw the attention of the Council to any aspects of media and make a recommendation [11].

Apart from the Complaints' Committee, there is also an Appeals' Committee which is charged with the responsibility of hearing appeals and dismissing, reducing or enhancing the discussions of the complaints committee [11]. In order to make for fair and transparent disposal of cases, membership of both committees is open to persons other than media professionals. Of the nine members of the Complaints Committee only four are from the media while only one member of the three-member Appeals Committee is from the media fraternity.

The complaint statistics for 2005, the years of its inception, indicate a total of twelve complaints and the complaints were laid by individuals and organizations. One complaint each was lodged by politicians, political parties, government departments, institutions/public bodies, religious groups and publications. And grievances were in the areas of imbalance, accuracy, invasion of privacy [11].

\section{Literature Review}

\section{Press Councils and Media Regulation}

Attempts to make journalism a respected profession and ensure that media professionals follow strictly the professions' code of ethics have remained a concern over the years. The use of underhand methods, though justifiable like in the Watergate scandal which exposed unethical practice in high places, to gather information even in the guise of public interest can be carried too far. The Guardian in Britain, for instance, intent on proving that a former MP, Jonathan Aitken, was corrupt sent a fax on the letter head of the House of Commons to 
the Ritz Hotel purporting that it emanated from the law maker. Later on, the Editor of the paper acknowledged that it was a "stupid and discourteous thing to have done" [7].

Public figures, big business and others who get into the news on the basis of the application of the news judgment criteria express, in many instances, deep misgivings about how news is reported and issues treated. A number of critics view the media as irresponsible, self-serving, unaccountable and a threat to the African democratic process with their stock in trade being uncivilized political propaganda and for engaging in biased and unethical behavior [12] [13].

A survey of rejoinders by public figures and corporate bodies in Nigeria revealed the scant regard that these entities have for journalism practice in the country. Akpabio [14] noted that there were more adversarial than mild rejoinders and the language used to describe publications and reporters calls for deep reflections about where journalism is headed:

... rebuttals accused the publications of being "unprofessional and highly misleading," "libelous and tendentious," "as well as a study in imaginative journalism." [News] Stories were also described as "literary collections of idle gossips," and as "containing innuendos and gross misrepresentations," as well as "outright falsehoods and distortion of facts amongst others". Of course journalists were not left out in the adversarial rejoinders. Their reports were described as the "figment of the writers imagination", "the handiwork of evil minds" and "fabrication of an overcharged imagination."

The whole province of ethical journalism is fluid indeed. Graphic details are blacked out by some media and others carry same with some advisory. Many are circumspect about revealing identities of minors who commit violent crimes. Many other borderline issues are a matter of much soul searching by gatekeepers at various levels. Other factors also affect the slant of the news: advertisers, by financing the media, come to expect better images and they do get it; freebies and junkets from public relations sources close up the chinks in the armour of persons and corporations and; ownership which is gravitating from moguls and barons to big business makes the media a part of a chain with all the attendant horizontal and vertical integration advantages which also impacts the news in more ways than one [2] [15] [16].

These and more reasons have informed media regulation, code of ethics and press councils. Christians, Fackler, Rotzoll, and McKee [17] hold that in borderline cases regarding what to publish or withhold, many operate at the evocative, expressive level-that, with no justifying reasons and then retreat to using the law as a guide. The authors rather favour a pattern of ethical deliberations in which weights are assigned to various aspects of the issue-like protecting minors, the public's right to know, truth telling, privacy etc. They also acknowledge that it is quite a complicated process.

News organizations also have codes of ethics (apart from the codes drawn up 
by professional bodies) that are well thought-out and dealing with a variety of scenarios, yet these have not dammed the many cases of ethical violations. The BBC's scrupulously clean image was rubbished by a series of scandals involving members of staff calling into phone-in programmes and passing off as members of the public and even by the network announcing the name of a fictitious winner on air [18].

Awards have been returned or cancelled because it was later revealed that the piece which sounded too good to be true was actually too good to be true! These kinds of excesses spawned calls for a statutory press council in Hong Kong with powers to impose fines on newspapers and curb invasion of privacy [19].

Frost [7] notes that press councils' workings differ from country to country. In Sweden, for instance, the press code's focus is on gathering of news material while that of Britain is more on the subject matter to be published although he also acknowledged that due to public pressure stronger clauses on harassment and privacy have been added. As regards enforcement, it can be through the law or a statutory body or both. The statutory body can be one's peers which have the power to delicense a practitioner or a mix of media professionals and lay people who can condemn bad practice or level a penalty. This latter system operates in Western European countries. Continuing, he notes that the Swedes and Dutch journalists stick to media ethics even though they have greater leeway to manipulate the codes. The British system is a different kettle of fish; as journalists stretch the codes to breaking point unless there is legislation.

In South Africa under Apartheid, President P.W. Botha had warned that if the press failed to put its house in order, the government would take action [20]. The result was the setting up of a press council. The Press Ombudsman replaced the council and it is made up of industry and public representatives. Its workings are virtually the same as that of the Botswana Media Complaints Committee. The same disposition under Apartheid as regards control of the media was present in the communist systems of Eastern European countries [21]. Both systems involve control over the media through administrative mechanisms and coercion. However, while the former has to do with state-media relations and ways in which control is exerted, the latter deals with production and dissemination of meanings [21].

Freedman [22] notes that in the U.S. and UK "participation of an expanded number of interest groups is perhaps the greatest challenge to traditional modes of media policy formation". This effectively means that policy makers pandering to the interests of big media corporations do not exclusively make the rules that shape the media in these countries. Freedman credits the Parent Television Council in the U.S. for increasing the fines that are imposed for "broadcast indecency" on American networks as well as a campaigning group, Public Voice, for the "public interest test" that major media mergers are subjected to in the UK.

All in all, the degree to which the media is controlled or regulated speaks vo- 
lumes of the democratic credentials of any government. Democratic governments allow the media free rein and favour self-regulation but totalitarian ones seem intent on exercising control. It must also be noted that many countries fall between the two extremes. But there can be no doubt that if the media curb their excesses the spectre of government regulation might not arise. Tettey [12] hit the nail on the head when he observed that "There is a legitimate argument that suggests that the lack of introspection and responsibility on the part of the media is directly related to the freedoms that they now enjoy in many countries on the [African] continent".

\section{Objectives of the Study}

The main objective of the study was to carry out a review of the mandate and activities of the Media Complaints/Appeals Committees. And more specifically:

1) To critically examine the Media Complaints/Appeals Committees performance in the light of their mandate.

2) To seek the views of media organizations and complainants on the intervention of the Media Complaint and the Appeal Committees.

\section{Research Questions}

Flowing from the above-enumerated objectives, the study sought answers to the following research questions:

1) What constitutes the attitude and disposition of complainants and the media to the activities and rulings of the Media Complaint/Appeal Committees?

2) How do members of the Media Complaint/Appeal Committees view their work/activities?

\section{Methodology}

The study utilized in-depth interviews because they assist in the collection of detailed information as well as provide greater latitude in fully exploring the topic under investigation [23] [24]. They also allow for observation of respondents' nonverbal responses and are customized to individual respondents thus throwing more light on the subject under investigation [24]. Two research assistants were contracted to conduct interviews with members of the Media Complaints/Appeal Committees, media professionals and complainants about their views on cases adjudicated upon. A total of eighteen respondents (see Table 1) were interviewed. These persons were purposely chosen because of their involvement either as complainants, respondents to complaints or because of their role as committee members.

\section{Findings}

\subsection{Attitude of Complainants towards the Media Complaints and Appeals Committees}

Complainants were largely dissatisfied with the committees' work by citing undue 
Table 1. Breakdown of interviewees.

\begin{tabular}{cc}
\hline Type of Interviewee & No of Persons \\
\hline Complainants & 6 \\
Editors & 6 \\
Members of Media Complaint Committee & 4 \\
Members of the Appeal Committee & 2 \\
Total & 18 \\
\hline
\end{tabular}

delays in disposing of cases and ineffective rulings. A complainant was very resentful, and stated that taking one's matters to the council was a "waste of time" because cases take a long time to dispose of. She was irked by the fact that her matter took more time to dispose of than the statutory time limit because the committee could not form a quorum.

Other complainants were dissatisfied with the composition of the committees. They argue that even though it is a noble idea to have journalists in such committees, this creates an unfavorable atmosphere. They question the degree of impartiality of such journalists. In fact, some respondents accused some members of the committees of being friends with the editors of offending newspapers, and therefore will invariably favour their friends when making rulings.

Related to this was the perceived bias in rulings of the committees. Complainants believe that the rulings of the Committees tend to favor the newspapers. They attribute this to composition of the committees, and argue that journalists influence other committee members to make rulings that favour their media organizations.

Complainants were also unhappy about the Committees' lack of enforcement of rulings. They argued that the Committees do not make an effort to ensure either their rulings, retractions or rejoinders are given the necessary prominence. They were of the view that the Committees should be enforcing this and making it their duty to ensure their rulings are given the necessary prominence in the offending publications.

In a case involving a newspaper that clearly identified a rape victim, an interviewee said that the newspaper ignored the ruling of the media complaints committee and there was nothing anybody could do about this. The ruling was that the newspaper should apologize to the complainant and publish an apology to that effect. Some of the complainants interviewed agreed that the setting up of the committee was a noble idea but noted that the inability to impose sanctions on non-compliant media houses defeats their purpose.

Some of the study respondents alleged that in instances where they bring it to the attention of the committees the fact that the retraction that was published was not given the necessary prominence they were told to lodge a fresh complaint. An interviewee noted that:

Then you find yourself going [round] in circles. This is exactly what hap- 
pened to me and the two matters were shelved. Failure to adhere to the ruling as I have said is due to the weakness of the Botswana Press Council committees. The way forward is to abolish the committees. They are a waste of time and government resources. We, as complainants, will as usual resort to the courts of law.

Complainants also decry the tone of the rulings. They stated that the language used in the rulings is not compelling, and the rulings are more advisory in nature, lack a forceful tone and use mild language. They, therefore, tend to doubt the seriousness of the committees.

Another complainant, whose case was dismissed expressed dissatisfaction with the way his matter was handled. He blamed the media for rushing to publish unsubstantiated allegations all in an effort to make more and more money without any consideration for the reputation of persons and institutions at the receiving end of such bad press. To curb this problem, he felt that the mandate of the committee should be extended to the pre-publication process so that such unsubstantiated stories are not given space or air time.

Although most respondents are dissatisfied with the Media Complaints Committee, one respondent, gave kudos to the committee and its work. In their matter, the ruling was in his considered opinion "fair and balanced" and his organization's complaint was "fairly addressed". He, however, felt that there was room for improvement. He noted that media houses do not comply fully with the committee's rulings and called for public education as well as imposition of sanctions on offending publications to ensure compliance.

\subsection{Attitude of Media Houses towards the Media Complaints and Appeals Committees}

Media houses were largely satisfied with the operations of the Committees, and unanimously agree that there is need to enforce compliance with the rulings of the committees. Most interviewees acknowledged that although the committee is relatively new, it has discharged itself creditably. A news Editor captured the general sentiments of fellow editors when he stated that the Committees are "work in progress" but nonetheless a "welcome development".

Interviewees agreed that there are varying levels of compliance to the rulings of the Committees by media houses. One editor was of the view that his newspaper always complied fully with rulings. Another editor said that there has been a high level of compliance by the media with the rulings of the committee. He noted that as a media house they do not agree with some of the committee's rulings but they have learnt "to live with it". Another editor echoed these sentiments:

We see a lot of value in supporting a self-regulatory authority because for us to operate as a professional enterprise we have to abide by certain rules... Because they are professional and ethical issues they can be painful to any publication; being told that you have to publish two pages in your newspa- 
per attacking yourself, but we have come to accept that the rulings may be difficult but they have to be [complied with]...

With regard to one of the rulings that went against his newspaper, another editor stated that his paper published the retraction in "visible pages" and contended that not giving the retraction the same prominence as the original offending report does not make for "lesser journalism". Another Editor whose paper was indicted by the committee stated that he looks at the bigger picture of higher journalism practice noting that "in some instances we feel the judgment delivered on [sic] us is hard but... necessary". One of the editors was of the view that lack of compliance was usually within the government-owned media, which she says has its own established way of dealing with media queries.

One of the editors was of the view that the media complaints committee is a good idea as it assists in resolving the inevitable disputes that is bound to arise between journalists and the people they write about. He sees the Botswana Media Complaints Committee as a vehicle for safeguarding ethical and professional standards of the media industry as well as a platform for aggrieved members of the public to air their views about offending media reports. Another interviewee said that the Committee is a welcome development in that it has offered an opportunity for redress to offended readers who may not have the means to go through expensive litigation processes.

Another editor was of the firm view that the Press Council as well as the Media Complaints Committee has upped professional and ethical practice in the Botswana media environment. However, some editors like complainants, emphasized the importance of the committee having the power to enforce its rulings.

The editors were of the view that the Press Council and the Media Complaints Committee need to educate the public about the roles of the committees. An editor notes that in spite of public education embarked upon by the committee through the media and Kgotla $a^{1}$ meetings, the public and particularly complainants still do not fully understand the mandate of the committee. He thus calls for more public education campaigns as regards the working and mandate of the committee. Another editor emphasized the need for media houses to support this initiative by giving adequate publicity to the mandate of the committee. Another editor was of the view that even the Media Complaints Committee members need some training and education.

Funding was singled out as one of the factors other than educational campaigns impeding the committee's work. Interviewees suggested that media houses should financially support the committees. One of the editors warned against soliciting government funding despite the committees' poor financial standing, arguing that state funding will come with "strings attached", and defeat the logic of self-regulation.

As to be expected, the Editors expressed total aversion against the govern-

${ }^{1}$ Communal meetings held as designated locations built specifically for this purpose in Botswana. 
ment-established statutory press council. An editor argued that "self-regulation is a very important tool and has to be supported by all stakeholders; statutory regulation is a not acceptable at all. Internationally, the world is going for self-regulation." Another stated that the statutory council set up by the government is an evil wind that will blow no good towards the media industry. A similar sentiment was expressed by another editor:

It is regrettable that we are in the situation that the press council is threatened; I think the members of the press council will work hard to make it survive when it is facing rivalry from the government. Surrendering self-regulation is like sabotaging democracy. Media shouldn't be regulated by the government. They should take self-regulation seriously; it is been eroded every day, members should stand up for self-regulation.

\subsection{Attitude of Members of the Media Complaints and Appeals Committees to their Work}

Members of the Complaints and Appeals committees are generally satisfied with their work in that they are able to execute their mandate to the best of their abilities. However, they were quick to express concerns about the public's lack of understanding of the committee's mandate, noncompliance to their rulings and insufficient funding for their activities.

A member of Media Complaints' Committee notes that rarely are their decisions upturned by the Appeals' committee; in his view, a clear testimony to the thorough work the committee is doing. The committee, in his view, dispenses inexpensive justice to aggrieved parties which would not be the case if they took the litigation route. In addition, one committee member was also pleased that very few cases handled by his committee are appealed. He acknowledged that it is also possible that complainants may not take the case forward to the Appeal Committee because they would have been exhausted from the effort expended at their committee.

Regarding lack of public understanding of their mandate, the former observed that there is a lot of ignorance as regards the work of the committee:

For instance, there is a stipulated time frame for lodging complaints and once the time has elapsed; the committee cannot entertain such matters. The committee attempts to provide adjudication based on the media code of ethics and after its rulings those at the receiving end, be they media houses or members of the public, feel frustrated that they did not win. This, he regards as a "normal kind of frustration".

He noted that the media at the inception of the committee was very cooperative by complying with rulings but as time went by, compliance was more in the breach. Media houses refused to publish the committee's rulings especially in instances where the rulings do not favour them. Other committee members shared similar sentiments with one of them using the term "stubborn" to refer to news- 
papers that refused to comply with the rulings. A committee member, who is a proponent of self-regulation, contends that compliance has been questionable, and that could be one of the main reasons that government had to reconsider statutory regulation. Another member noted that it is ironical that the media sets up a committee and then refuses to cooperate with it by complying with its rulings.

Two of the committee members pointed an accusing finger at the government-owned Botswana Television and Daily News as examples of media houses who openly flout their rulings. In the view of one of the members, cases of non-compliance by the private press are minuscule compared to the flagrant disregard exhibited by the government media.

A recurring decimal in the operations of the press council is funding. Committee members mentioned funding as a challenge to the work of the committee, as it limits the extent to which they can engage in public education about the Committees. One member insists that funding is the bane of the committee's operation noting that there is no secretariat to operate from because of financial constraints. They noted that the situation is not helped by media organizations who fail to offer publicity and public education about the media complaint committee.

Members of the Complaints Committee decried a situation where there are two parallel councils on the ground as this is confusing. One member was of the opinion that the self-regulating mechanism should have been nursed to maturity instead of the coming into being of the statutory press council which has muddied the waters asking: "Which council should aggrieved parties approach?"

On the Appeal Committee side, a member felt that they had very little to do and that in a given year they might hear 2 - 3 cases. But those parties were usually satisfied by their rulings. However, while the government media openly flouted their rulings, the private press "frustrated" same. For instance, if they were told to publish a retraction in the front pages of their newspapers, they would do so in very small print. He commended the parties for always providing all the necessary documents that facilitated the work of the Appeals Committee. He was also of the view that the verdicts were delivered in a timely manner. On the issue of enforcement of rulings he had a somewhat different perspective:

Given a little bit more power, but power to do what? What can you do really when the government media say we are not going to listen to you? The idea was that this should be a self-regulatory body, even if we fine them who would enforce the fine?... I don't believe that the Media Complaints and Appeals Committees should be holding a carrot and a big stick; I think it should be volunteering. Journalists are professionals and they should set up their own code of conduct and regulations and adhere to [same], unless they are not professionals. The media must follow the sanctions they have agreed to; if they don't, then the whole structure crashes and it means that self-regulation can't work. 
Another member of the Appeals Committee was satisfied with the makeup of the committee (a practicing attorney, a religious leader/community leader and a public relations practitioner) that guaranteed its independence and the timely disposition of cases to the satisfaction of all parties. He noted that most cases involved newspapers with a few complaints about radio stations but that most of the complainants were politicians. He felt that the cases they handled were mostly from urban areas and he called for more public education about the work of the committees as well as proper administrative structures to aid the committee's work.

\section{Conclusions}

Clearly, the Botswana Media Complaints and Appeals Committees were set up under the aegis of the Botswana Press Council with the best of intentions. While there are accusations from complainants that the committees were made up of media professionals who invariably favoured their friends in the media, the findings of this study indicate that the media have been at the receiving end of the committees' rulings.

So where did things go wrong? While the media subscribed to the setting up of the committees, they must have had very different expectations. Perhaps they thought the committees would favour them in their rulings and when they realized that the reverse was the case, they decided to throw spanners in the works. The private media, in spite of their protestations to the contrary, failed to fully comply with the rulings of the committee which they had voluntarily set up with a view to avoiding government regulation. The government-owned media really set a bad example given their reach and impact. The state broadcaster, Botswana Television (BTV) was for a long time the only TV station in the country and Daily News is the highest circulating daily. So when these big media players do not want anything to do with the rulings of the committees, it leaves a bad taste in the mouth.

The public on the other hand also has unmet expectations about the press councils and its organs; nothing public education could not have corrected. But given the poor financial situation of the press council and its organs as well as the non-cooperation by the media in educating the public, the recipe for failure was already in place. More so, given Silverstone's [25] assertion that a responsible and accountable media culture depends on a critical and literate citizenry, which is critical with respect to, and literate in the ways of mass mediation and media representation.

It was under the cover of this Babel that the government set up a statutory press council. But is this the solution? It is true that when the media are not able to put their house in order and are given to excess which is clearly the case in Botswana, the government steps in. But in this instance there are now two press councils which serve to complicate the situation. The private media are completely averse to the statutory press council but they would also not swallow 
their self-medicated drugs. The governement-owned media, naturally would subscribe to the statutory press council but where do aggrieved members of the public go to get remedy for bad press? The object lesson from the Botswana scenario is that if the media are effective in their self-regulation initiatives, this will likely keep government-initiated statutory press councils at bay.

As in every study, there are also limitations of this study. The voice of government media is notably absent in this study but it is also doubtful given the public service code if media professionals in government would be willing to respond to issues that will paint them or their principal in bad light. Other researchers may wish to tackle this angle. A content analysis of how publications treated retractions they were expected to publish would also be another useful research angle. All in all, the study is significant as it gives a Botswana perspective to the debate about self-regulation versus statutory regulation and provides convincing evidence to support the literature that if self-regulation is not effective, it gives goverment the excuse to step in with a statutory press council. Jurisdictions in which these debates are raging or are of ongoing concern can borrow a leaf from these findings.

However, citizen involvement in press and media regulation and affairs seems to be absent in Botswana. It is clear from the literature that their involvement, especially because they are the consumers and target of the media, can be quite useful in guiding policy and regulations. Perhaps citizen pressure groups can help break the present impasse. Such groups must also take an active interest in media policy formulation so as to guarantee that all subsequent laws and guidelines are in the overall interest of the public. In the West, there is a clearly a movement away from media policy being the exclusive preserve of technocrats and media corporations to citizen involvment [22]. Given the Botswana scenario in which the government and the private press are locked in mortal combat for the soul of the media, clearly indicating that the two have failed to put their house in order, it is about time for the citizenry to take their proper place in order to have the kind of media and media regulation they want.

\section{Acknowledgements}

Eno Akpabio is now with the Department of Information and Communication Studies, University of Namibia.

\section{References}

[1] Akpabio, E. (2004) Media Image of the Nigerian Military. In: Olurode, L. and Anifowoshe, R., Eds., Democratization and the Military in Nigeria, Friedriech Ebert Stiftung, Lagos, 174-187.

[2] Akpabio, E., Katunzi, A. and Njonjo, M. (2013) The Impact of Ownership on Editorial Independence in Tanzanian Media: A Survey of Journalists and Media Managers. In Media Council of Tanzania, Media Research Papers 2012, 1-31.

[3] Olukotun, A. (2002) State Repression, Crisis of Democratization, and Media Resistance in Nigeria (1988-1999). College Press Ltd., Ibadan. 
[4] Mclachlan, T. (2015) South Africa: New Self-Regulation Council for Press. http://allafrica.com/stories/200705310661.html

[5] Press Council South Africa. (2016) http://www.presscouncil.org.za/

[6] African Media Development Initiative. (2006) Research Summary Report. BBC World Service Trust, London.

[7] Frost, C. (2000) Media Ethics and Self-Regulation. Longman, London.

[8] Ifex (2001) Botswana Media Bill Raises Concern. https://www.ifex.org/botswana/2001/12/05/botswana_media_bill_raises_concern/

[9] IFJ. (2001) IFJ Condemns "Dangerous” Draft Media Law. https://www.ifex.org/botswana/2001/12/03/ifj_condemns_dangerous_draft_media/

[10] Press Council of Botswana (n.d.) Notarial Deed of Trust. http://www.pcbotswana.org/downloads/Press_Council_Deed_of_Trust.pdf

[11] (2005) Media Complaints and Appeals Committee Annual Report.

[12] Tettey, W. (2006) The Politics of Media Accountability in Africa. The International Communication Gazette, 68, 229-248. https://doi.org/10.1177/1748048506063763

[13] Media Council of Tanzania (n.d.) "Die Hard" Political Orientation Affects Election Coverage.

http://www.mct.or.tz/index.php/component/content/article/42-news/rokstories/393 -die-hard-political-orientation-affects-election-coverage

[14] Akpabio, E. (2004) Direction of Nigerian Newspapers Rejoinders. Nordic Journal of African Studies, 13, 188-199.

[15] Croteau, D. and Hoynes, W. (2001) The Business of Media: Corporate Media and the Public Interest. Pine Forge Press, Thousand Oaks.

[16] Croteau, D., Hoynes, W. and Milan, S. (2012) Media/Society: Industries, Images, and Audiences. Sage, Los Angeles.

[17] Christians, C., Fackler, M., Rotzoll, K. and McKee, K. (2001) Media Ethics: Cases and Moral Reasoning. Longman, New York, 2.

[18] The Telegraph (2015). http://www.telegraph.co.uk/news/uknews/1557839/The-guilty-BBC-programmes.ht $\underline{\mathrm{ml}}$

[19] Weisenhaus, D. (2005) News Gathering Practices: Hong Kong Journalists Views on Use of Controversial Techniques. Global Media Journal, 4, 1-16.

[20] Nel, F. (2001) Writing for the Media in Southern Africa. Oxford University Press, Cape Town.

[21] Jakubowicz, K. (1995) Media within and without the State: Press Freedom in Eastern Europe. Journal of Communication, 45, 125-139. https://doi.org/10.1111/j.1460-2466.1995.tb00758.x

[22] Freedman, D. (2006) Dynamics of Power in Contemporary Media Policy-Making. Media and Society, 28, 907-923. https://doi.org/10.1177/0163443706068923

[23] Berger, A. (1991) Media Research Techniques. Sage Publications, Thousand Oaks.

[24] Wimmer, R. and Dominick, J. (2006) Mass Media Research: An Introduction. Thomson/Wadsworth, Belmont.

[25] Silverstone, R. (2004) Regulation, Media Literacy and Media Civics. Media, Culture and Society, 26, 440-449. 